\title{
Determinants Of Foreign Direct Investment In The Manufacturing Industry: A VectorAutoregression Model Approach
}

\author{
Symon Elli R. Blas ${ }^{a}$, Laurence P. Usona ${ }^{b}$ \\ ${ }^{a}$ Graduate School, Polytechnic University of the Philippines, Philippines \\ ${ }^{\mathrm{b}}$ Department of Mathematics and Statistics, Polytechnic University of the Philippines, Philippines
}

Article History: Received: 10 November 2020; Revised 12 January 2021 Accepted: 27 January 2021; Published online: 5 April 2021

\begin{abstract}
This paper aimed to identify the factors that affect Foreign Direct Investment (FDI) in the manufacturing industry using a Vector Autoregression (VAR) model. The researcher selected possible economic indicators (Agriculture, Consumer Price Index, Government Expenditure and Unit Labour Cost) through theories and empirical evidences from various researches, covering quarterly period of 2004-2018. The result showed that there is a significant relationship between FDI and the selected economic indicators. It also revealed that shocks agriculture produces a positive impact, as well as government expenditure. However, consumer price index when introduced to shocks showed an immediate negative impact. On the other hand, unit labor cost did not have a significant impact on the foreign investments. The future variability of FDI primarily depends on itself, while the selected indicators affect roughly one-tenth of the future values of FDI
\end{abstract}

Keywords:

\section{Introduction}

Theeconomic performance of the Philippines in the past decade, gauged by the Gross Domestic Product (GDP), moved erratically in the first few years and a steady growth in the latter years. This pattern indicates that the Philippines exhibited a stable to increasing economic growth.

In 2018, Philippines experienced 6.2\% economic growth, which was below the bounds of the National Economic Development Authority's (NEDA) 2018 GDP target of $6.5 \%$ to $6.9 \%$. One of the reasons of low growth rate was due to the decline in the exports of goods and services from $19.5 \%$ to $11.5 \%$ in 2017 . However, the decrease was tempered by the increase of government spending from $7.0 \%$ in 2017 to $12.8 \%$ in 2018 , and influx of capital formation (domestic and foreign investments) from 9.4\% in 2017 to $13.9 \%$ in 2018.

The GDP composition of industries is another way to assess the economic growth of a country. Construction was the most improved industry in 2018 with $15.9 \%$ growth, greatly surpassing its 2017 growth of $5.3 \%$. Likewise, public administration and defense, and compulsory social security increased from $7.8 \%$ in 2017 to $14.6 \%$ in 2018. Manufacturing industry had seen a slow down after two consecutive increases, staying at $4.9 \%$.

Manufacturing is one of the biggest industries in the Philippines. Based on PSA, this industry contributed $19.1 \%$ or PhP3.32 trillion in 2018 GDP - the highest contributor. There are about 116,766 manufacturing establishments based on the 2016 List of Establishment of the PSA, of which 1,1018 $(0.9 \%)$ were large enterprises, $963(0.8 \%)$ were medium enterprises, 11,998 (10.3\%) were small enterprises and 102,787 (88.0\%) were micro enterprises. Likewise, it is the fourth $\left(4^{\text {th }}\right)$ contributor to the employment in the Philippines for the year 2018. In PSA's Labor Force Survey (LFS), manufacturing is estimated to have provided 3.63 million jobs or $8.8 \%$ of the total employed persons.

One of the driving factors that drive a country's economy to grow is its flow of investments. Investments are used to increase the productivity and efficiency of a business. Usually, developing countries, like the Philippines, attract foreign investments through adopting preferential policies (i.e., income tax holidays) that encourage foreign investors to invest.

In 2018, FDI inflows in the country fell by 33.3\%, from US\$3.4 billion in 2017 to US\$2.27 billion in 2018. This was primarily due to low investments in electricity, gas, steam and air-conditioning industry from US\$1.39 billion in 2017 to US\$0.19 billion in 2018. However, industries such as financial and insurance activities, and arts, entertainment and recreation were greatly boosted with $133.2 \%$ and $576.6 \%$ growth, respectively. Even though manufacturing industry investments waned by $8.46 \%$, it was the highest contributor to FDI with US $\$ 1.80$ billion contribution or $47.7 \%$ of the total FDI. 
In 2018, Department of Trade and Industry (DTI) launched the Inclusive Innovation Industrial Strategy (i $\left.{ }^{3} \mathrm{~S}\right)$ to produce more and quality jobs, while attaining inclusive and sustainable growth. The $i^{3} S$ goal is to grow innovative and globally competitive sectors (agriculture, manufacturing and services), through strengthening the linkages of these sectors in the domestic and global value chains (GVC). To develop industries, the strategy will focus on linking together activities, mainly on design, R\&D, engineering, after sales with manufacturing, as well as addressing challenges and constraints of each industry on the following identified priority sectors: a) auto and auto parts; b) electronic manufacturing services; c) aerospace parts and aircraft maintenance, repair and overhaul; d) chemicals; e) shipbuilding and ship-repair; f)furniture, garments, creative industries; g) iron and steel, tool and die; h) agribusiness; i) construction; j) Information Technology-Business Process Management (IT-BPM); k) transport and logistics; and 1) tourism.

\section{Expiremnetal Method}

Various data from the Philippine Statistics Authority (PSA), Bangko Sentral ng Pilipinas (BSP) and Bureau of Treasury were identified to assess FDI. Evaluating the identified variables was approximated by the different statistical indicators such as: a) agriculture was sourced from the agricultural gross value added (GVA) in constant 2000 prices; b) government spending through the expenditure of the National Government Cash Operations of the Bureau of Treasury; c) economic stability used the consumer price index (CPI) with 2012 as its base year; and d) unit labor cost (ULC) was the value of the commodity created per person employed. Some variables have undergone another transformation to remove their seasonality components. Consumer price index, FDI, Government expenditure, and unit labor cost may be influenced by seasonality factors.

The study mainly used the Vector Autoregression (VAR) model of the multivariate single equation, removing the contemporaneous effect of the variables and the lagged effects of the variables, while taking into account the long-run effects of the model. Process from diagnostic tests and residual analysis were followed.

The study measured the significant factors that can attract foreign investments in the manufacturing industry. Furthermore, it also showed the impacts of shocks, as well as their variability effects, to the future values of FDI.

a
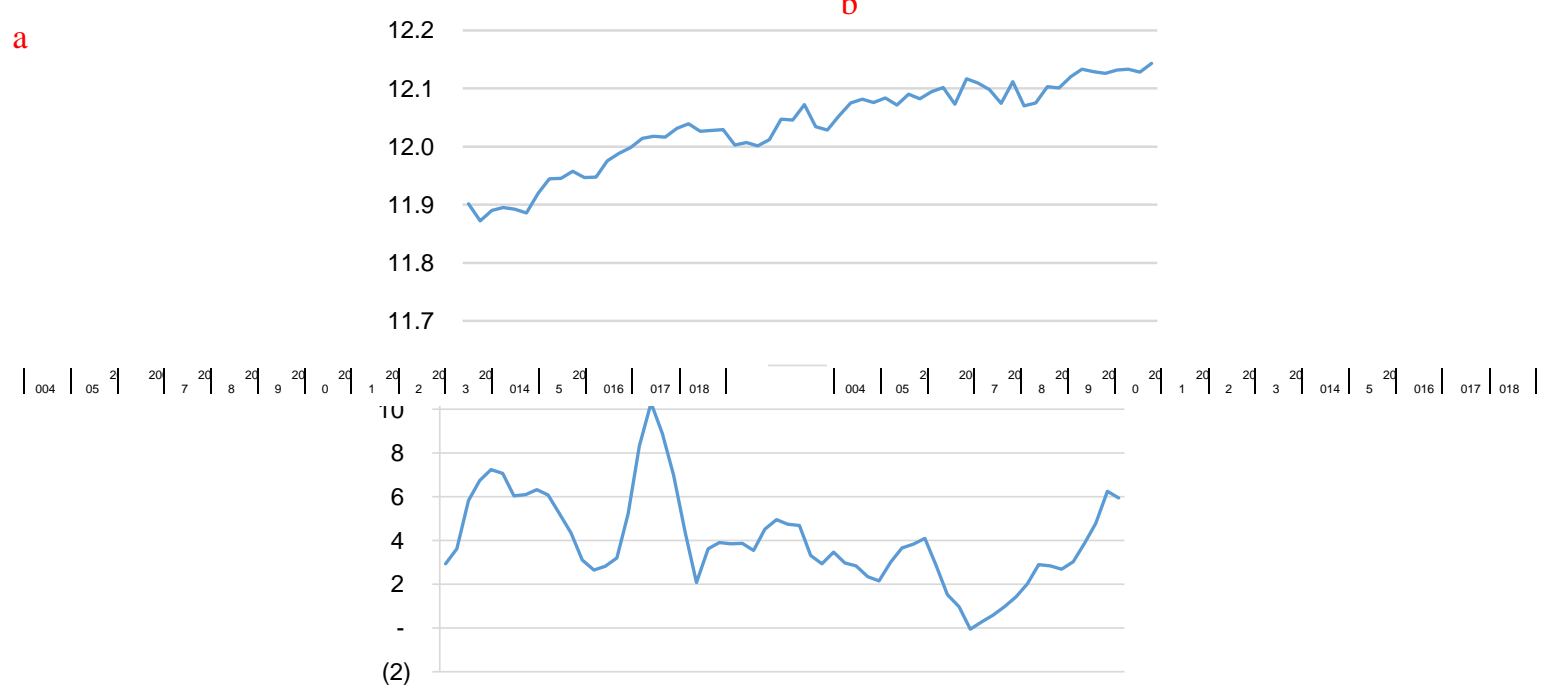

Fig. 1 - Quarterly Behavior of: (a) Agriculture and (b) Economic Stability

It can be noted that there was a small increase in the agricultural productivity in the country from 2004 to 2009. However, it also shows that an almost stagnant to smaller increase was shown in 2010 to 2018 . The agriculture sector has the smallest share to the gross domestic product; every year the share is decreasing bit by bit. This is primarily due to the shifting of the agriculture sector to different industries and services. According to the survey deployed by the Department of Agriculture, the average age of farmers in the Philippines is 60 years old. This is primarily due to the disinterest of the new generation in the agriculture sector as well as the risk of investing due to weather conditions.

The Economic Stability, graphed through the inflation rate, of the country for the past 15 years can be seen with highs and lows. Recently, the Philippine Statistics Authority (PSA) rebased the base year of the Consumer Price Index (CPI) of the country to 2012. This was primarily due to restructuring of the economy and the inclusion of other factors that were not covered during the 2000 base year. The period 2008 had the highest inflation rate during the course of 15 years. This was primarily due to the global rice crisis where the Philippines is a net importer of rice; since rice is an inelastic commodity in the Philippines, when prices of rice skyrocketed from its manageable prices and the demand for rice does not change. In this scenario, and the rice is the most heavily 
weighted in the CPI, inflation rate in the country skyrocketed. Likewise, a consistent increase in the latter part of the graph can be seen. This was mainly due to the introduction of the Tax Reform for Acceleration and Inclusion (TRAIN) law in the country. Even before the passage of first $\left(1^{\text {st }}\right)$ package of the law, prices of commodities particularly sugar, increased in the prices in micro industries, thus affecting consumer expenditure.
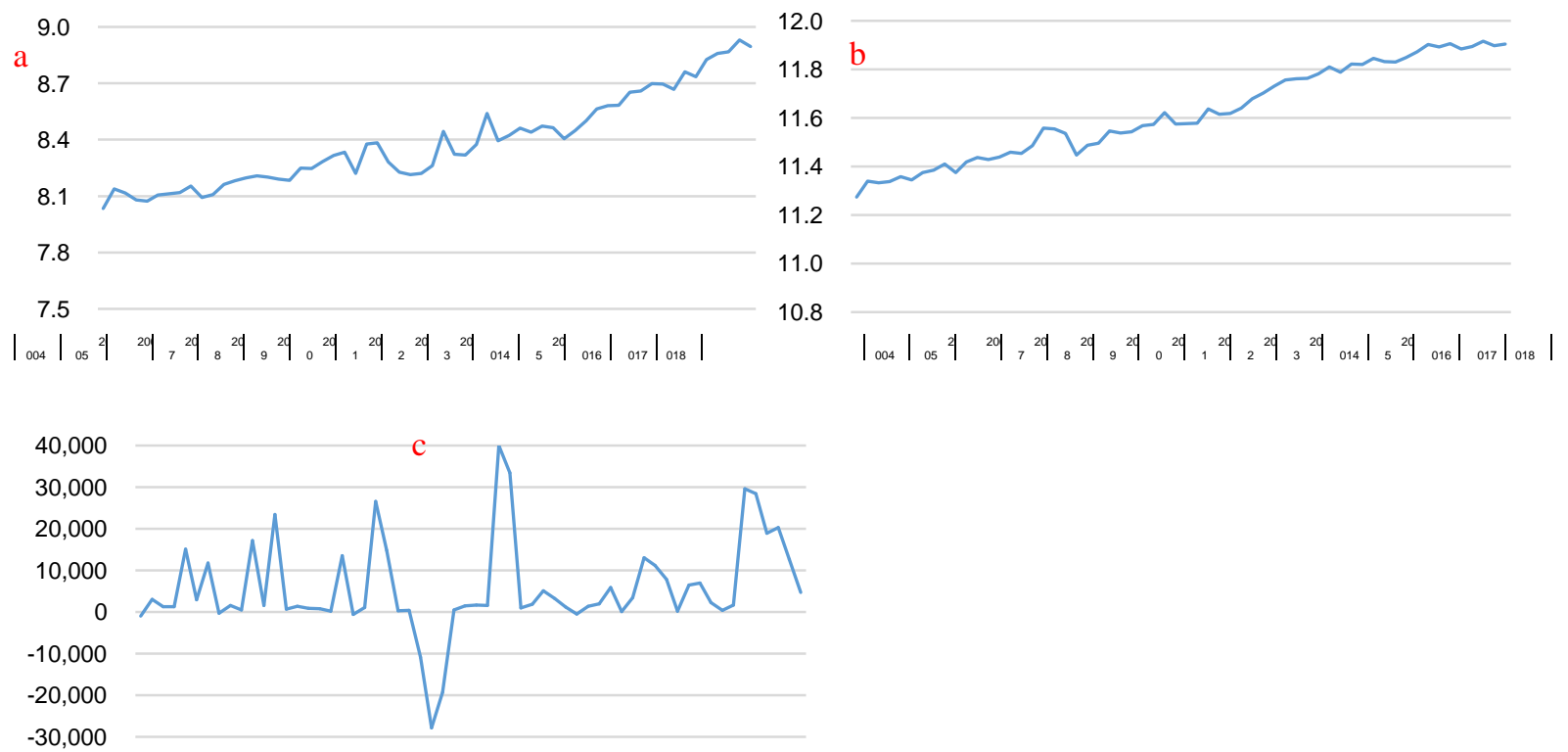

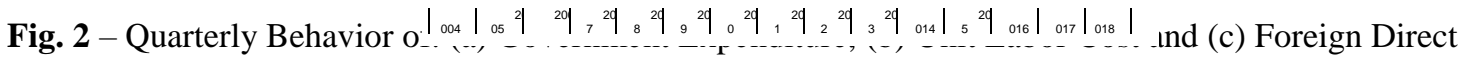
Investment

The behavior of the government expenditure during the last 15 years was noticeably increasing. It is noted in the graph that from 2004 to 2010 there was a rapid and continuous increase, while a stagnant to slow increase was noted from 2010 to 2015 and a sudden increase from 2015-2018. This is primarily due to the approach or style of the government during different government administration. In 2004 to 2010, the Arroyo administration lump sum appropriation, while Aquino administration used a bottom-up budgeting resulting to slow spending. On the other hand, Duterte administration is very keen on the Build, Build, Build program that addresses infrastructure requirements of the country.

The above graph shows a constant increase in the pattern of the unit labor cost. The series is defined by the ratio of manufacturing Gross Value Added (GVA) by the total persons employed in the manufacturing industry. A high labor cost is due to the disparity of the value of production to the total number of persons working in the industry. It can be noted that in 2009 there was a decrease in the labor cost due to the decrease in the value of production in manufacturing with only a minimal decrease in the persons employed. On the other hand, the latter part of the series can be as a plateaued case, where the ratio of the labor cost from 2016 to 2018 did not differ from one another.

The Foreign Direct Investments (FDI) has no clear patterns on the manufacturing investments of foreign nationals in the country. It can noted that in 2010 there was a huge decline in the FDI, mainly due to the global financial crisis which happened in the United States that affected many countries, thus their withdrawal of investments in many countries. Furthermore, many international companies have closed down their operations in the Philippines and head to other countries, due to high cost of electricity and water, lack of infrastructure and poor logistics. However, investments in the country have been increasing in bit by bit due to the manufacturing resurgence program of the government.

\subsection{Determinants of Foreign Direct Investments}

To determine the factors that attract foreign direct investments in the manufacturing industry, the researcher used the Vector Autoregression (VAR) model. The use of the VAR model is to identify the dynamics of the most endogenous variable to other variables. Likewise, the model can only specify the relationship of the variables and not their degree of interaction with the dependent variable. 


\begin{tabular}{|c|c|c|c|}
\hline Variable & Order of Integration & $\begin{array}{rr}\text { ADF } & \text { Test } \\
\text { Statistic } & \end{array}$ & p-value \\
\hline FDI & Level & -4.68 & 0.00 \\
\hline \multirow[t]{2}{*}{ Agriculture } & Level & -1.78 & 0.38 \\
\hline & $1^{\text {st }}$ Difference & -10.12 & 0.00 \\
\hline \multirow[t]{2}{*}{ Economic Stability } & Level & -1.82 & 0.37 \\
\hline & $1^{\text {st }}$ Difference & -3.80 & 0.00 \\
\hline \multirow[t]{2}{*}{ Government Expenditure } & Level & 1.10 & 1.00 \\
\hline & $1^{\text {st }}$ Difference & -7.95 & 0.00 \\
\hline \multirow[t]{2}{*}{ Unit Labor Cost } & Level & -1.06 & 0.73 \\
\hline & $1^{\text {st }}$ Difference & 6.76 & 0.00 \\
\hline
\end{tabular}

Table 1. Stationary Test of the Determinants of Foreign Direct Investment

The unit root test tests the stationarity of the series. A stationary series is defined as there are no trends or constant increase/decrease patterns in the series and revolve around the value zero. Based from the results of the Augmented Dickey-Fuller (ADF) test the following were observed:

1. The foreign direct investments (FDI) series is stationary at level.

2. The Agriculture series is stationary at the first (1st) difference.

3. The Economic Stability series is stationary at the first (1st) difference.

4. The Government Expenditure series is stationary at the first (1st) difference.

5. The Unit Labor Cost series is stationary at the first (1st) difference.

Looking through the results and from the behavior of the variables, it can be concluded that there existed a trend component in Agriculture, Economic Stability, Government Expenditure and Unit Labor Cost. On the other hand, FDI showed an erratic pattern that portrayed a stable series. Even though the test signified a presence of unit roots in some variables, it should be tested for cointegration.

Based from the results of the Johansen System of Cointegration test on level, all equations were not cointegrated, since it produced a probability value of 0.11 which is higher than the 0.05 significance level, thus satisfying the null hypothesis that there is a cointegrating relationship between variables. Therefore, the variable series does not have an interrelationship through time. With the rejection of cointegration at hand, the values were differenced before including in the model. This process transformed series into a stationary series that can be used in the model. Afterwards, the model was tested for the length of lags values it can contain.

The lag length selection process can determine the optimum lag values of the series that can be accommodated in the model or it can limit the number of past values that can affect the present values. Using the Akaike Information Criterion (AIC) that tests the goodness-of-fit of the lag values of the series, proposes that the lowest AIC is the recommended number of lags to be included in the model. Based from the AIC, the lowest value occurred on the fifth (5th) lag with 1.46 units. This suggests that highest possible lags that the model can accommodate are within five (5) preceding periods.

\subsection{Var Model Estimation}

The vector autoregression model estimates the dynamic relationship of the variables to the most endogenous variable (FDI). The model only interprets the relationship of the variables, while setting-aside the weights of the variable affecting the dependent variable.

Based from the estimates of the vector autoregression model, the following were observed:

1. The first (1st) lag value of FDI produced t-statistic of 2.91 which was higher than the expected t-statistics of 1.645 and the fifth (5th) lag value produced t-statistic of -2.97 which was lower than expected t-statistics of 1.645. Therefore, past values of FDI have a significant relationship with the current FDI.

2. The third (3rd) and fourth (4th) lag values of the Agriculture produced t-statistics of 2.17 and 3.19, respectively, which were higher than the expected t-statistic of 1.645. Therefore, Agriculture has a positive significant relationship with FDI.

3. The second (2nd) lag value of the Unit Labor Cost produced t-statistic of -2.27 , which was lower than the expected t-statistic -1.645. Therefore, Unit Labor Cost has a negative significant relationship with FDI. 
4. The second (2nd) and fourth (4th) lag values of the Government Expenditure produced t-statistics of 2.17 and 3.19, respectively, which were higher than the expected t-statistic of 1.645. Therefore, Government Expenditure has a positive significant relationship with FDI.

5. The second (2nd) and fifth (5th) lag values of the Economic Stability produced t-statistics of -1.88 and 2.96 , respectively which were lower than the expected t-statistic of -1.645 , and the fourth (4th) value produced $t-$ statistics of 3.80 which was higher than the expected t-statistic of 1.645. Therefore, Economic Stability has a significant relationship with the FDI.

Although there relationships existed between the identified variables and FDI, the model cannot be generalized unless it is subjected to residual and model diagnostics. Residual and model diagnostics test the following for a holistic analysis of the model: 1) autocorrelation of error terms; 2) error terms are normally distributed; 3) variances of the error terms are consistent through time; 4) stability of the VAR model; and 5) misspecification of variables.

\subsection{Residual Analysis}

\subsubsection{Autocorrelation}

The autocorrelation of the residuals tests if the error terms of the model followed a specific pattern. Autocorrelated residuals may specify missing information that must be included in the model or may use a higherorder VAR model to explain the autocorrelation. The LM-Statistics tests the model up to the 12th lag, determining if the residual terms are dependent on one another. Based from the results, the LM-Statistics probability values were less than the confidence level, thus satisfying the null hypothesis that there exists no residual autocorrelation on the model series. Therefore, the error terms of the model do not follow a specific pattern and do not depend on other error terms.

\subsubsection{Normality}

The normality of the residuals tests if the error terms of the model response in a randomly order and consistent throughout the series. Non-normal distribution of the model may specify that the error terms are not behaving independently or the model can be tested using the volatility of the variances of the model. Based from the JarqueBera test, the test showed a probability value of 0.89 which is higher that the confidence level, thus satisfying the null hypothesis that the distribution of the residual of model was normally distributed. Therefore, the error terms were independent from one another and followed a random and consistent errors.

\subsubsection{Heteroscedasticity}

The heteroscedasticity of the model was tested to compute the consistency of the variances through time. A heterscedastic model suggests that the error terms variances are different in through time and problem with wide range of values, and suggest to identify the reason behind extreme values. Based form the white-noise test, the test showed a probability value of 0.47 , higher than the 5 significance level, thus satisfying the null hypothesis that the model is heteroscedastic. Therefore, the variances of the error terms in the model are consistent through time.

\subsubsection{Model Stability}

The VAR model does not guarantee that all lag variables are included in the model; the model is subjected for stability to determine if all lag values of the variables are accepted. If the model resulted in instability, the lag value that causes the instability was omitted. Based from the inverse roots of autoregression characteristic polynomial, all of the lag variables in the model have roots and modulus with less than one value, thus satisfying that all roots and modulus are within the unit circle. Therefore, all lag values that were considered in the model are stable.

\subsubsection{Block-Exogeneity Test}

Exogeneity of the FDI was tested to determine if the identified dependent variable is the most endogenous variable and the determinants have a direct relationship FDI. Based from the Block-Exogneity Wald tests, the results showed that all variables are less than significance level, thus rejecting the null hypothesis that FDI is exogenous. Therefore, there are no misspecifications present in the model and FDI is endogenous in terms of the identified variables.

The model satisfied all residual and model diagnostics. Therefore, the following observations can be generalized:

1. Agriculture has a significant positive relationship with FDI. As stated by Dinda (2009) the endowment of natural resources as a factor in inputs for production in exports mainly encourages FDI. 
2. Economic Stability has a conflicting relationship with FDI. The immediate preceding increase in the consumer price index (CPI) showed a significant negative relationship to the current FDI as indicated in various researches (Udoh and Egwaikhide, 2008; Omankhanle, 2011; Jabri et al., 2013; Valli and Masih, 2014; Fanbasten and Escobar, 2016; and Alshamsi, 2018). On the other hand, the 4 periods before the current CPI denoted a significant positive effect. Khan (2010) noted that the effect of inflation rate can be positive due to the foreseen economic growth of a country.

3. Government expenditure resulted to a significant positive relationship with FDI as supported by Ifeakachukwu et al. (2013) and Othamn et al. (2018). The government spends its budget to build infrastructure for a good market environment and subsidize other industries to increase their productivity.

4. Unit Labor Cost showed a significant positive relationship with FDI. This is in contrast with many researches that used wage as their variable for Unit Labor Cost. The structure of the Unit Labor Cost in the Philippines was very high; this may translate to the persons employed in the manufacturing industry who were highly skilled (Demirhan and Masca, 2008).

\section{Impacts of Variable's Shocks and Variability to Future Values of FDI in the Manufacturing Industry}
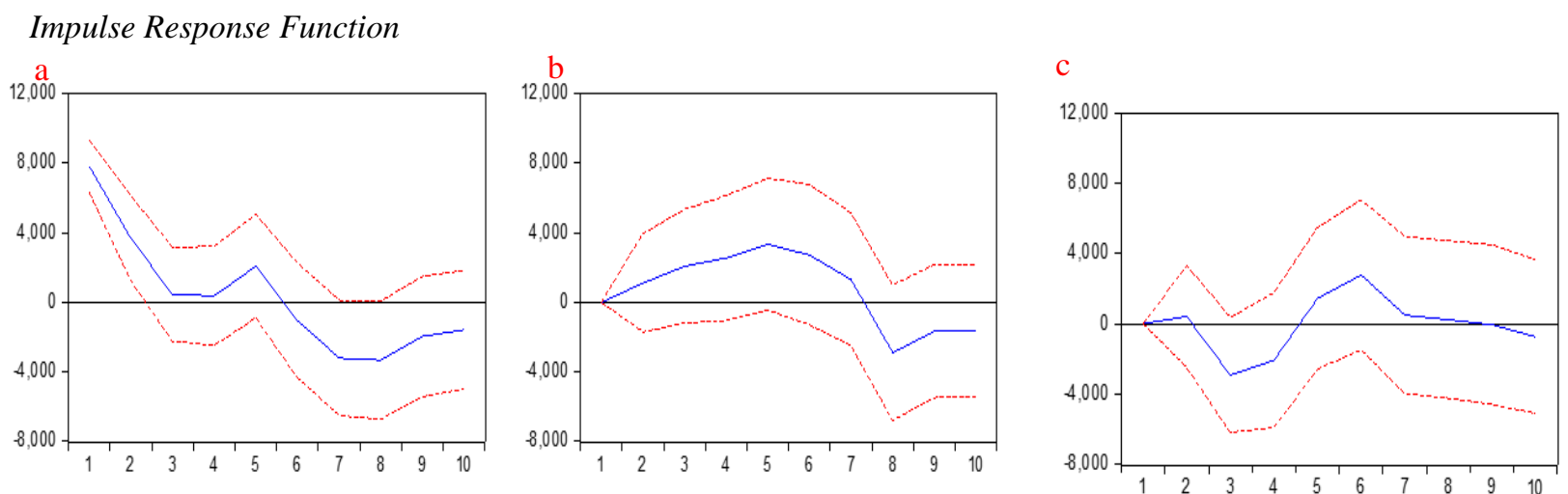

$\mathrm{d}$
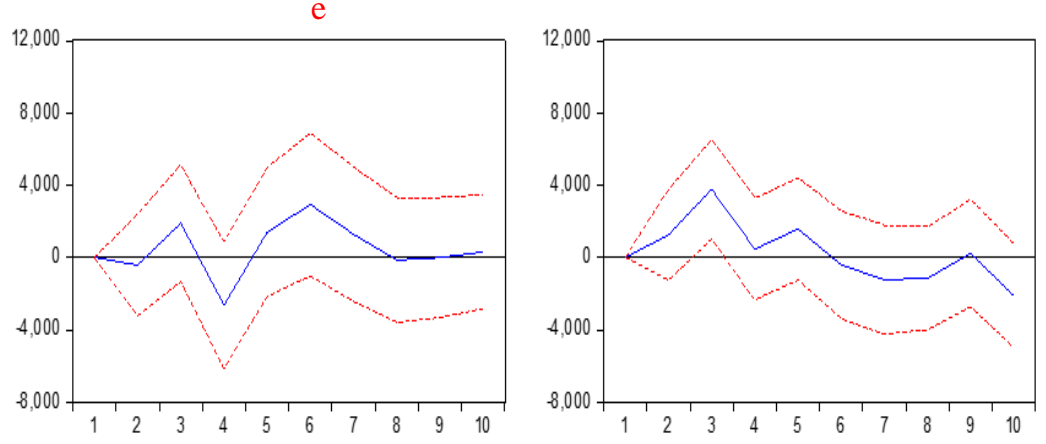

Fig. 3 - Variable's Shock to the change in FDI (a) FDI, (b) Agriculture, (c) Economic Stability, (d) Unit Labor Cost and (e) Government Expenditure

Based from the impulse response function, the following observations were derived:

1. Response of FDI to shocks to the introduction of shocks to itself will yield a positive effect in the five (5) periods and negative effect after 5 periods.

2. Response of FDI to the introduction of shocks to the Agriculture will not yield immediately affect foreign direct investments. The effect will only show second (2nd) to seventh (7th) periods after, while a negative effect afterwards.

3. Response of FDI to the introduction of shocks to the Economic Stability will not yield an immediate effect to the foreign direct investments, until third (3rd) period to fourth (4th) period, while making a positive effect on the fifth (5th) and sixth (6th) period, before dying out afterwards.

4. Response of FDI to the introduction of shocks to the ULC will not yield an immediate effect to the foreign direct investments, until a positive effect in the third (3rd) period. However, succeeding periods value, including standard errors, linger in the zero value.

5. Response of FDI to the introduction of shocks to the government expenditure displays that the introduction of a positive shock from Government Expenditure will not yield an immediate effect to the foreign direct investments. The effect will only show second (2nd) to fifth (5th) periods after, while a negative effect afterwards. 
Variance Decomposition Analysis

\begin{tabular}{|c|c|c|c|c|c|}
\hline Perio & FDI & $\begin{array}{c}\text { Agricult } \\
\text { ure }\end{array}$ & $\begin{array}{c}\text { Economic } \\
\text { Stability }\end{array}$ & $\begin{array}{c}\text { Government } \\
\text { Expenditure }\end{array}$ & $\begin{array}{c}\text { Unit Labor } \\
\text { Cost }\end{array}$ \\
\hline 1 & 100.00 & - & - & & - \\
\hline 2 & 95.98 & 1.58 & 0.22 & 1.97 & 0.24 \\
\hline 3 & 69.00 & 5.07 & 7.99 & 14.46 & 3.48 \\
\hline 4 & 59.26 & 9.46 & 10.24 & 12.57 & 8.48 \\
\hline 5 & 53.41 & 15.54 & 10.14 & 12.36 & 8.56 \\
\hline 6 & 46.36 & 17.57 & 13.13 & 10.68 & 12.26 \\
\hline 7 & 48.01 & 17.05 & 12.19 & 10.62 & 12.12 \\
\hline 8 & 48.50 & 19.35 & 11.01 & 10.20 & 10.93 \\
\hline 9 & 48.79 & 20.02 & 10.68 & 9.92 & 10.15 \\
\hline 10 & 47.64 & 20.29 & 10.43 & 11.48 & \\
\hline
\end{tabular}

Table 2. Variance Decomposition Analysis

Based from the impulse response function, the following interpretations were derived:

1. The forecast variance of foreign direct investments due to itself, started from $100 \%$ in the first period, declining to $50 \%$ in the sixth (6th) period and after.

2. The forecast variance of foreign direct investments due to Agriculture is only minimally visible after the third (3rd) period and increasing to $20 \%$ afterwards.

3. The forecast variance of foreign direct investments due to Economic Stability is only minimally visible after the third (3rd) period and stabilizing after at $11 \%$ afterwards.

4. The forecast variance of foreign direct investments due to Government Expenditure is only minimally visible after the third (2nd) period and stabilizing at $11 \%$ afterwards.

5. The forecast variance of foreign direct investments due to Unit Labor Cost does not have variability on the first term and minimally visibly at the third (3rd) and stabilizing at 10\% to $12 \%$ afterwards.

\section{Conclusion}

Agricultural output of the country is a major factor for attracting foreign investments (Dinda, 2009). A strong linkage of the agriculture and manufacturing should be established, since the manufacturing industry particularly food manufacturing has a large backward linkage that transforms raw agriculture output to a more value added commodity (Gouk, 2012).

Consumer price index produces a negative relationship in attracting foreign investments (Udoh and Egwaikhide, 2008; Valii and Masih, 2004; Fanbasten and Escobar, 2016). However, its effect towards foreign investments is minimal and later on will die out (Jabri et al., 2013) and might signal a strong economic activity in the future based from the speed of the market to adapt to sudden price increase.

Unit labor cost can positively attract foreign investments (Saglam and Boke, 2017). However, introduction of shocks to unit labor cost does not have a clear impact on FDI (Demirhan and Masca, 2008). This could be attributed to the stabilization of the ratio of the production and employment in the manufacturing industry.

Government expenditure has a positive effect on the foreign investments (Ifeakachukwu et al., 2012). The continuous efforts of the government to subsidize major industries have shown to increase business market environment in the country, thus attracting foreign investments. However, the type of expending in the political side might cause disruption on the flow of disbursement of funds.

After the simulations of tests and conclusions, the following recommendations are suggested:

1. The agricultural industry needs to be strengthened. The output of the industry must not stay at its current level and should be transformed into a higher level of produce. Likewise, the linkage of the industry to other industries, as well as the vital role of the academe and the government should be seen as an opportunity to revive agriculture.

2. With the forthcoming of the industrial revolution in the Philippines, workers in the sector that might be replaced due to automation and should pursue a skill enhancement on their current skills. 
3. The consumer price index or the inflation rate should be controlled at the target level of the government. Likewise, future research may focus on the speed of the stabilization of the inflation rate.

4. The government should use its fund more appropriately, such as allotment to expenditures that will help the agriculture sector to revive. Furthermore, future research may also look further on the formation of fixed capital.

5. The study has a lot of limitations. The following are recommended for future researches:

- $\quad$ Use of socio-political (i.e., political risk) and monetary parameters (i.e., interest rates);

- Competitiveness and its parameters (i.e., electricity cost, fuel cost, logistics);

- $\quad$ Assessment and/or tracking of the Investment Promotion Agencies (IPAs) approved investments; and

Comparison of other country foreign direct investments and indicators to the Philippine model

\section{References}

Alam, A. and Shah S. (2013). Determinants of foreign direct investment in oecd member countries, Journal of Economic Studies, 40(4). Retrieved from https://www.researchgate.net/publication/263523888_Determinants_of_ foreign_direct_investment_in_OECD_member_countries

Aldaba, R. M. (2017). The Philippines in Agribusiness Global Value Chains: Introduction, DTI Policy Briefs.

Alshamsi, K. (2018). The impact of inflation and GDP per capita on foreign direct investment: The case of United Arab Emirates, Investment Management and Financial Innovations, 12(13-1), 132-141. Retrieved from https://businessperspectives.org/images/pdf/applications/publishing/templates/article/assets/6875/imfi_en_20 15_03cont_Alshamsi.pdf

4. Al-Eitan, G. (2013). Modeling inward foreign direct investment for Jordan and Australia: A comparative study. Retrieved from https://espace.curtin.edu.au/bitstream/handle/20.500.11937/395/195895_AlEitan\%202013-.pdf? sequence=2

Artige, L. and Nicolini, R. (2009). Market potential, productivity and foreign direct investment: Some evidence from three case studies. Retrieved from https://core.ac.uk/ download/pdf/36076586.pdf

Asiamah, M et al. (2018). Analysis of the determinants of foreign investment in Ghana, Journal of Asian Business and Economic Studies. Retrieved from https://www.emeraldinsight.com/ doi/pdfplus/10.1108/JABES-08-2018-0057

Awan, A et al. (2014). Factors affecting foreign direct investment in Pakistan. Retrieved from http://www.eajournals.org/wpcontent/uploads/Factors-Affecting-Foreign-Direct-Investment-in-Pakistan.pdf

Azam, M. and Lukman, L (2010). Determinants of foreign direct investment in India, Indonesia and Pakistan: A quantitative approach. Retrieved from http://www.qurtuba.edu.pk/jms/default_files/ JMS/4_1/02_azam.pdf

Blonigen, B. and Piger, J. (2011). Determinants of foreign direct investment.” NBER Working Paper No. 16704. Retrieved from https://www.nber.org/papers/w16704.pdf

Cuyvers, L. et al.. (2008). Determinants of foreign direct investment in Cambodia: Country-specific factor differentials. Retrieved from https://repository.uantwerpen.be/docman/irua/.../430b1df3.pdf

Da Silveria et al.. (2017). Determinants of foreign direct investment in Brazil: Empirical analysis for 2001-2013, CEPAL Review No. 121. Retrieved from https://repositorio.cepal.org/bitstream/ handle/11362/42016/1/RVI121_ Triches.pdf

.Demirhan, E. and Mahmut M. (2008). Determinants of foreign direct investment flows to developing countries: A cross-sectional analysis," Prague Economic Papers 4.

Department of Trade and Industry (DTI) (2017). Philippine Inclusive Industrial Innovation Strategy (i3S), DTI Policy Briefs Series No 2017-05

Dinda, S. (2009). Factors determining FDI in Nigeria: An empirical investigation. Retrieved from https://mpra.ub.uni-muenchen.de/40172/1/ MPRA_paper_401 72.pdf

Enisan, A. (2017). Determinants of foreign direct investment in Nigeria: A markov regime-switching approach." Retrieved from https://hrcak.srce.hr/ file/266842

Ekanayake, E. and Kornecki, L (2011). Factors affecting inward foreign direct investment flows into the United States: Evidence from state-level data. Retrieved from cejsh.icm.edu.pl/cejsh/ element/.../MIBE_T12_z1_05.pdf

Fanbasten, N. and Escobar, A. (2016). Determinants of foreign direct investment: A panel data analysis of the MINT countries." Retrieved from http://uu.diva-portal.org/smash/ get/diva2:939333/FULLTEXT01.pdf

Gebrewold, T. (2012). Determinants of foreign direct investment inflows to Africa." Retrieved from http://hj.diva-portal.org/smash/get/diva2: 572643/FULLTEXT01

Giavidou, M. (2016) "The Effect of Certain Factors on FDI Attraction: A Cross Country analysis. Retrieved from https://brage.bibsys.no/ xmlui/bitstream/handle/11250/2455942/Desember-16\%20Maria.pdf?sequence=1 
Granneman, A. and Dijk, M. (2015). Foreign direct investment in China, the factors determining a preference for investing in eastern or western provinces. Retrieved from https://file.scirp.org/pdf/ME_2015082715270527.pdf

Gouk, S. (2012). Linkages between agriculture and food industry, and food processing by farmers in Korea, Journal of Rural Development 35(2), pages 103-118. Retrieved from https://ageconsearch.umn.edu/bitstream/175280/2/35_2_5.pdf

Hoa, D. and Lin J. (2016). Determinants of foreign direct investment in Indochina: A holistic approach, International Journal of Business and Applied Social Science, 2(1). Retrieved from https://ijbassnet.com/storage/app/publications/56bc0d8d2ecf011455164813.pdf

Ifeakacukwu, N. et al. (2013). An analysis of the relationship between public spending components and private investments in Nigeria, Journal of Finance and Economics, Volume 1 Issue 2. Retrieved from http://todayscience.org/ JFE/article/jfe.v1i2p14.pdf

. Jabri, A. et al. (2013). Determinants of foreign direct investment in the MENA Region: Panel co-integration analysis, The Journal of Applied Business Research 29(4). Retrieved from https://www.researchgate.net/publication/

289003110_Determinants_Of_Foreign_Direct_Investment_In_MENA_Region_Panel_Co-

Integration_Analysis

. Jadhav, P. (2012). Determinants of foreign direct investment in BRICS economies: Analysis of economic, institutional and political factor, Procedia - Social and Behavioral Sciences 37 (2015) 5-14. Retrieved from https://www.sciencedirect.com/science/article/pii/S1877042812007495

.Karau, J. and Mburu, T. (2016). Institutional, governance and economic factors influencing foreign direct investment inflows in East Africa." Retrieved from http://jedsnet.com/journals/jeds/ Vol_4_No_3_September_2016/7.pdf

Khan, M. and Khattak, N. (2009). Effects of economic factors on foreign direct investment inflow: Evidence from Pakistan (1971-2005). Retrieved from https://www.aup.edu.pk/sj_pdf/ EFFECTS $\% 200 F \% 20$ ECONOMIC\% 20FACTORS\%20ON\%20FOREIGN\%20DIRECT\%20INVESTMENT\%20INFLOW\%20EVIDENCE\%20F ROM\%20PAKISTAN\%20_1971-2005_.pdf

Khrawish, H. and Siam, W. (2010). Determinants of direct foreign investment: Evidence from Jordan. Retrieved from https://ageconsearch. umn.edu/bitstream/95943/2/10_V1_JORDAN_BEH_Husni\%20Ali\%20Khrawish_Walid \%20Siam_d.pdf

Kohler, A. (2013). Income distribution, market size, and foreign direct investment. Retrieved from https://www.econ.uzh.ch/dam/jcr:00000000 7972-abe4-0000-0000737e4df5/Kohler_FDI_ Marketsize_Mai2013.pdf

.Kummanont, S. (2014). Analysis of factors influencing the decision of Japanese investors to direct investment in Thailand. Retrieved from http://iosrjournals.org/iosr-jbm/papers/Vol16-issue1/Version-7/G016174757.pdf

Ludosean, B (2012). A VAR analysis of the connection between fdi and economic growth in Romania, Theoretical and Applied Economics, Volume XIX, No 20 (575), pp. 115-130. Retried from http://store.ectap.ro/articole/789.pdf

Luiz, J. and Charalambous, H. (2009). Factors influencing foreign direct investment of South African Financial services firms in Sub-Saharan Africa. Retrieved from https://econrsa.org/ system/files/publications/working_papers/wp118.pdf

Mangir, Faith et al. (2012). Determinants of foreign direct investment: A comparative analysis of Turkey and Poland, Economic and Environment Studies, Vol 12, Issue 1, pp 65-86. Retrieved from https://www.econstor.eu/ bitstream/10419/93211/1/755683706.pdf

Miskinis, A and Juozenaite, I (2015). A comparative analysis of foreign direct investment factors, Ekonomika Vol. 94(2) Retrieved from www.zurnalai.vu.lt/ekonomika/article/ download/ 8230/ 6101

Missama, A. (2015). Analysis of factors affecting foreign direct investment flows into agricultural sector in Tanzania. Retrieved from http://suaire.suanet.ac.tz:8080/xmlui/bitstream/handle/123456789/284/ADDO\%20 ADDO \%20MISAMA\%202010.pdf?sequence=1\&isAllowed=y

Mohamed, O. (2018). Vector autoregressive analysis - VAR: Foreign direct investment and unemployment: Sudan, 1990-2016, Global Journal of Economics and Business - Vol. 4. No. 2, pp 224-235. Retrieved from http://www.refaad.com/Files/GJEB/GJEB-4-2-6.pdf

.Mohamed, S. and Sidiropoulos, M. (2010). Another look at the determinants of foreign direct investment in MENA countries: An empirical investigation, Journal of Economic Development, Volume 35 Number 2. Retrieved from http://www.jed.or.kr/full-text/35-2/5.pdf

Mottaleb, K. and Kalirajan, K. (2010). Determinants of foreign direct investment in developing countries: A comparative analysis," ASARC Working Paper 2010/13. Retrieved from https://asiaandthepacificpolicystudies.crawford.anu.edu.au/acde/asarc/pdf/papers/2010/WP2010_13.pdf 
Mutua, R. (2016). Factors influencing foreign direct investment on construction: A case of real estate projects in Nairobi Country, Kenya. Retrieved from http://erepository.uonbi.ac.ke/ bitstream/handle/11295/97818/Mutua

Factors \%20Influencing\%20Foreign \%20Direct\%20Investment\%20In\%20construction,\%20\%20A\%20Case \% 20Of\%20Real\%20Estate\%20Projects\%20In\%20Nairobi\%20County,\%20Kenya.pdf?sequence=1\&isAllowed $=\mathrm{y}$

Omankhanlen, A. (2011). The effect of exchange rate and inflation on foreign direct investment and its relationship with economic growth in Nigeria. Retrieved from http://eprints.covenantuniversity .edu.ng/1896/1/Alex\%201.pdf

Othman, N. et al. (2018). Impact of government spending on FDI Inflows: The case of ASEAN-5, China and India, International Journal of Business and Society, Vol. 19 No.2. Retrieved from http://www.ijbs.unimas.my/images/ repository/pdf/Vol19-no2-paper10.pdf

O’Meara, G. (2015). Examining the determinants of foreign direct investment, Undergraduate Economic Review, Volume 11 (1); Art. 13. Retrieved from https://core.ac.uk/download/pdf/ 59231696.pdf

Peng, W. (2011). VAR analysis of foreign direct investment and environmental regulation: China's case, Business and Economic Horizons, Volume 5, Issue 2. Retrieved from https://pdfs.semanticscholar.org/950d/55553d3 2118e3b89b1e9fb9cd902c7b065ee.pdf

Phung, H. (2016). Determinants of FDI into developing countries, Mark A. Israel '91 Endowed Summer Research Fund in Economics, 4. Retrieved from https://digitalcommons.iwu.edu/ cgi/viewcontent.cgi?article $=1004 \&$ context $=$ israel_economics

Randelovic, M. (2017). Market size as a determinant of the foreign direct investment inflows in the Western Balkans Countries, Facta Universitatis, Series: Economics and Organization. 10.22190/FUEO1702093P. Retrieved from https://www.researchgate.net/ publication/320947085_Original_Scientific_Paper_MARKET_SIZE_AS_A_ DETERMINANT_OF_THE_FOREIGN_DIRECT_INVESTMENT_INFLOWS_IN_THE_WESTERN_BAL KANS_COUNTRIES_1

.Rjoub, H. et al.. (2017). Financial reforms and determinants of FDI: Evidence from Landlocked Countries in Sub-Saharan Africa, MDPI Journal Economies. Retrieved from https:/www.mdpi. com/2227-7099/5/1/1

Saglam, B. and Boke, S. (2017). Labor costs and foreign direct investment: A panel VAR approach. Retrieved from https://www.mdpi.com/2227-7099/5/4/36/pdf

Sakia, D. (2009). Agriculture-industry interlinkages: Some theoretical and methodological issues in the Indian Context, Munich Personal RePEc Archive. Retrieved from https://mpra.ub.uni-muenchen.de/27820/1/ MPRA_paper_27820.pdf

Serafim, T. (2011). The investment development path - literature review, Annals of the "Ovidius" University, Economic Sciences Series, Volume XI, Issue 1. Retrieved from https://www.researchgate.net/publication/22746 6209_The_Investment_Development_Path__Literature_Review

Siboleka, M et al.. (2014). Agriculture and manufacturing sector growth in Namibia during the period 1981 to 2012: A granger causality test, British Journal of Economics, Management and Trade 4(11):1700-1707. Retrieved from http://www.journalrepository.org/media/journals/BJEMT_20/2014/Jul/Siboleka4112014BJEMT9299_1.pdf

Tocar, S. (2018). Determinants of foreign direct investment: A review, Review of Economic and Business Studies, Volume 11. Retrieved from https://content.sciendo.com/view/journals/rebs/11/1/article-p165.xml

Udoh, E. and Egwaikhide, F. (2008). Exchange rate volatility, inflation uncertainty and foreign direct investment in Nigeria, Botswana Journal of Economics, 5(7). Retrieved from https://www.ajol.info/index.php/boje/article/ download/ 60304/48547

Valli, M. and Masih, M. (2014). Is there any causality between inflation and FDI in an 'Inflation Trageting' regime? Evidence from South Africa," Munich Personal RePEc Archive, 60246. Retrieved from https://mpra.ub.uni-muenchen.de/60246/1/MPRA_paper_60246.pdf

Walsh, J. and Yu, J. (2010). Determinants of foreign direct investment: A sectoral and institutional approach. Retrieved from https://www.imf.org/external/pubs/ ft/wp/2010/wp10187.pdf

Wani, N. and Rehman, N. (2017). Determinants of FDI in Afghanistan: An empirical analysis, MPRA Paper No. 81795. Retrieved from https://mpra.ub.uni-muenchen.de/81975/1/MPRA_paper_81975.pdf 